\title{
The Antimicrobial Peptide CopA3 Inhibits Clostridium difficile Toxin A-Induced Viability Loss and Apoptosis in Neural Cells
}

\author{
I Na Yoon ${ }^{1}$, Jae Sam Hwang ${ }^{2}$, Joon Ha Lee ${ }^{2}$, and Ho Kim ${ }^{1 *}$ \\ ${ }^{1}$ Divison of Life Science and Chemistry, College of Natural Science, Daejin University, Pocheon 11159, Republic of Korea \\ ${ }^{2}$ Department of Agricultural Biology, National Academy of Agricultural Science, RDA, Wanju 55365, Republic of Korea
}

\author{
Received: September 13, 2018 \\ Revised: November 6, 2018 \\ Accepted: November 8, 2018 \\ First published online \\ November 16, 2018 \\ ${ }^{*}$ Corresponding author \\ Phone: +82-31-539-1855; \\ Fax: +82-31-539-1850; \\ E-mail: hokim@daejin.ac.kr \\ pISSN 1017-7825, eISSN 1738-8872 \\ Copyright@ 2019 by \\ The Korean Society for Microbiology \\ and Biotechnology
}

\begin{abstract}
Numerous studies have reported that enteric neurons involved in controlling neurotransmitter secretion and motility in the gut critically contribute to the progression of gut inflammation. Clostridium difficile toxins, which cause severe colonic inflammation, are also known to affect enteric neurons. Our previous study showed that $C$. difficile toxin A directly induces neural cell toxicities, such as viability loss and apoptosis. In the current study, we attempted to identify a potent inhibitor of toxin A-induced neural cell toxicity that may aid in managing toxin A-induced gut inflammation. In our recent study, we found that the Korea dung beetle-derived antimicrobial peptide CopA3 completely blocked neural cell apoptosis caused by okadaic acid or 6-OHDA. Here, we examined whether the antimicrobial peptide CopA3 inhibited toxin A-induced neural cell damage. In neuroblastoma SH-SY5Y cells, CopA3 treatment protected against both apoptosis and viability loss caused by toxin A. CopA3 also completely inhibited activation of the pro-apoptotic factor, caspase-3. Additionally, CopA3 rescued toxin A-induced downregulation of neural cell proliferation. However, CopA3 had no effect on signaling through ROS/p38 MAPK/p27 $7^{\mathrm{kip} 1}$, suggesting that CopA3 inhibits toxin Ainduced neural cell toxicity independent of this well-characterized toxin A pathway. Our data further suggest that ability of CopA3 to rescue toxin A-induced neural cell damage may also ameliorate the gut inflammation caused by toxin $\mathrm{A}$.
\end{abstract}

Keywords: Bacterial toxin, gut inflammation, enteric nerve system, insect-derived antimicrobial peptide, apoptosis

\section{Introduction}

Clostridium difficile releases toxin $\mathrm{A}$ and $\mathrm{B}$, which are known to be the main causative factors of the inflammatory response to this pathogen in the gut $[3,14,17,20,23,27]$. Toxins enter target epithelial cells through binding to specific receptors on the plasma membrane, and through their enzymatic activity, inhibit Rho family proteins (Rho, Rac, cdc42) that are essential for cytoskeleton formation in epithelial cells; this, in turn, leads to severe cell rounding and results in disruption of the barrier function of epithelial cells $[6,12,13]$. The formation of toxin-receptor complexes is also reported to activate intracellular signaling pathways that trigger apoptosis in target cells $[12,13,20,23]$. In many types of cells, toxin A is known to produce reactive oxygen species (ROS), which activate p38 MAPK and upregulate $\mathrm{p} 21^{\text {Cip/Waf1, }}$ ultimately causing apoptosis [18, 19]. Thus, these factors and pathways are considered the main contributors to the disruption of epithelial cells that form the physical barrier and the triggering of inflammatory responses in the gut [18, 19].

Numerous studies have revealed that the enteric nervous system (ENS) is involved in pathophysiological processes in the gut $[2,7,26,33,34]$. For example, it has been reported that inhibition of the ENS is associated with intestinal infarction or spasm [7]. In contrast, inflammatory responses are known to activate sensory neurons [28]. In addition, mouse colitis models exhibit a marked change in intestinal neurotransmission [26]. C. difficile toxins in particular are known to stimulate enteric neurons; injection 
of toxin $\mathrm{A}$ into the lumen enhances neurotransmitter secretion, promotes gut motility [2], and inhibits sympathetic neurotransmission [33]. In our recent study, we found that toxin A directly induces a loss of cell viability and apoptosis in human neuroblastoma cells SHSY5Y, suggesting that the ENS is a potential therapeutic target for treating inflammatory responses caused by C. difficile toxins.

The antimicrobial peptide CopA3 (LLCIALRKK), a product of the Korea dung beetle (Copris tripartitus) identified by transcriptome analysis, has been reported to exert various effects, including inhibition of toxin A-induced colonic epithelial cell apoptosis and 6-hydroxydopamine (OHDA)induced neural cell apoptosis $[17,25]$, as well as stimulation of proliferation of both colonic epithelial cells and neural cells [17, 25]. Notably, CopA3 has been reported to ameliorate all inflammatory responses observed in various mouse inflammation models [17]. CopA3 is also known to reduce macrophage activation induced by lipopolysaccharide, suggesting an immunosuppressive effect [24]. Since these data collectively indicate the ability of CopA3 to inhibit various types of cell damage, we here tested whether CopA3 can rescue toxin A-induced neural cell damage. We also examined the therapeutic effect of CopA3 compared with other insect-derived antimicrobial peptides.

\section{Materials and Methods}

\section{Clostridium difficile Toxin A Preparation and Cell Culture}

Toxin A was purified from C. difficile strain 10463 (American Type Culture Collection, USA) as previously described [18]. The purity of the native toxin A was assessed by gel electrophoresis, which confirmed a single protein band at the expected molecular mass of $307 \mathrm{kDa}$. Human neuroblastoma SH-SY5Y cells were maintained in MEM containing 10\% FBS (Invitrogen, USA), 1\% penicillin (Gibco, USA), $1 \%$ L-glutamine, $1 \%$ HEPES in a $37^{\circ} \mathrm{C}$ humidified incubator with $5 \% \mathrm{CO} 2$ [35].

\section{Synthesis of Antimicrobial Peptides}

The following insect-derived antimicrobial peptides, synthesized by AnyGen (Gwangju, South Korea), were used in this study: P4 (RLLLAIGRG), P5 (RLWLRIGRG) and P6 (RLWLAIGRG), from Protaetia brevitarsis [15, 32]; HaGF (GEILHRFRRSFCDY) and HaA4 (IGGYCSWLRL), from Harmonia axyridis [21]; and CopA3 (LLCIALRKK), from C. tripartitus [11]. The synthesized peptides were further purified by reverse-phase high-performance liquid chromatography (HPLC) using a Capcell Pak $\mathrm{C}_{18}$ column (Shiseido, Japan), and were eluted with a linear gradient of wateracetonitrile $(0-80 \%)$ containing $0.1 \%$ trifluoroacetic acid $(45 \%$ recovery). The identity of peptides was confirmed by electrospray ionization mass spectrometry (Platform II; Micromass, United Kingdom) [4].

\section{Cell Viability}

SH-SY5Y cells were treated with various agents, then incubated with 3-[4,5-imethylthiazole-2-yl]-2,5-diphenyltetrazolium bromide (MTT) dye for $2 \mathrm{~h}$. The solubilization reagent was added, and absorbance was determined at $570 \mathrm{~nm}$ by a spectrophotometer (Model 3550; Bio-Rad, Canada) [35].

\section{Immunoblot Analysis}

SH-SY5Y cells were washed with cold phosphate-buffered saline (PBS) and lysed in a buffer containing $150 \mathrm{mM} \mathrm{NaCl}, 50$ $\mathrm{mM}$ Tris- $\mathrm{HCl}$ (pH 8.0), 5 mM EDTA, and 1\% Nonidet P-40. Equal amounts of protein were fractionated by SDS-polyacrylamide gel electrophoresis (SDS-PAGE). The appropriate antibodies were applied, and antigen-antibody complexes were detected with the LumiGlo reagent (New England Biolabs, USA) [30].

\section{Terminal Deoxynucleotidyl Transferase-Mediated Deoxyuridine} Triphosphate Nick-End Labeling (TUNEL) Assay

Cells were exposed to toxin A or toxin A plus insect peptide for $24 \mathrm{~h}$, and then fixed with $4 \%$ paraformaldehyde for $20 \mathrm{~min}$ at room temperature. Cells with fragmented nuclear DNA were detected by TUNEL assay (Promega, USA), according to the manufacturer's instructions [35].

\section{Measurement of ROS}

SH-SY5Y cells were incubated for 30 min with $50 \mu \mathrm{M}$ DCF-DA ( $2^{\prime} 7^{\prime}$-dichlorofluorescin-diacetate), and then treated with toxin A for $30 \mathrm{~min}$. Fluorescence intensity was analyzed with a Fluoroscan Ascent FL microplate reader (Thermo Fisher Scientific, USA) using $485 \mathrm{~nm}$ excitation and $538 \mathrm{~nm}$ emission filters [35].

\section{BrdU Cell Proliferation Assay}

The proliferation of cells exposed to toxin A or toxin A plus CopA3 was measured based on the rate of DNA synthesis using a BrdU Cell Proliferation Assay (Roche, USA), according to the manufacturer's instructions [17]. Briefly, SH-SY5Y cells $\left(1 \times 10^{4}\right.$ cells/well) were seeded in a 96-well microplate, treated with toxin $\mathrm{A}$ in the presence or absence of CopA3 for $24 \mathrm{~h}$, and then further cultured with the BrdU mixture for $24 \mathrm{~h}$. The cells were then fixed, incubated with the anti-BrdU antibody for $1 \mathrm{~h}$, and incubated with horseradish-peroxidase (HRP)-conjugated goat anti-mouse IgG for $30 \mathrm{~min}$. Absorbance at $450 \mathrm{~nm}$ was measured using a microplate reader [16].

\section{Statistical Analysis}

The results are presented as the mean values \pm SEM. Data were analyzed using the SIGMA-STAT professional statistics software program (Jande Scientific Software, USA). Analyses of variance with protected t-test were used for intergroup comparisons. 


\section{Results and Discussion}

The Antimicrobial Peptide CopA3 Inhibits Toxin A-Induced Viability Loss in Human SH-SY5Y Neuroblastoma Cells

C. difficile toxin $\mathrm{A}$, which causes colonic inflammation, is known to affect the function of the ENS [2, 33]; upon injection into the intestinal lumen, toxin $\mathrm{A}$ enhances neurotransmitter secretion, promotes gut motility, and suppresses sympathetic neurotransmission. In contrast, the ENS is also reported to be involved in the progression of the inflammatory response in the gut $[1,2,28]$. Building on two concepts that the ENS is a therapeutic target for the treatment of inflammatory responses in the toxin Aexposed gut and that a number of antimicrobial peptides have demonstrated beneficial effects in various human disease models $[5,22,31]$, we sought to identify insectderived antimicrobial peptides that could inhibit toxin Ainduced neural cell damage and thus serve as therapeutic agents. To this end, we incubated SH-SY5Y cells with $3 \mathrm{nM}$ toxin $\mathrm{A}$ in the presence of insect antimicrobial peptides $(10 \mu \mathrm{g} / \mathrm{ml})$ derived from $P$. brevitarsis (P4, P5, and P6) [15, 32], $H$. axyridis (HaGF and $\mathrm{HaA} 4)$ [21], or C. tripartitus (CopA3) [11] for $24 \mathrm{~h}$, and then measured cell viability by MTT [3-(4,5-dimethylthiazol-2-yl)-2,5-diphenyl tetrazolium bromide] assay. As shown in Fig. 1A, toxin A decreased cell viability by up to $30 \%$ in neural cells. This toxin Ainduced loss of viability was not attenuated by $P$. brevitarsis peptides (P4, P5, P6) or H. axyridis peptides (HaGF, HaA4) (Fig. 1B). P4, P5, P6, HaGF, or HaA4 alone did not cause neural cell toxicity. In sharp contrast, CopA3 from C. tripartitus significantly rescued the toxin A-induced loss of cell viability (Fig. 1C). CopA3 alone showed no cytotoxicity towards neural cells, suggesting that CopA3 exerts a protective effect against toxin A-induced neural cell toxicity without causing cell damage itself.

\section{CopA3 Inhibits Toxin A-Induced Neural Cell Apoptosis}

Next, we analyzed the inhibitory effect of CopA3 on toxin A-induced neural cell apoptosis. To this end, we incubated SH-SY5Y cells with toxin A in the presence or absence of CopA3 for $24 \mathrm{~h}$ and measured DNA fragmentation by TUNEL (terminal deoxynucleotidyl transferase dUTP nick-end labeling) staining. As shown in Fig. 2A, toxin A markedly increased the percentage of TUNEL-positive cells (i.e., cells with fragmented DNA reflecting apoptosis) compared with controls. Immunoblot analyses further revealed that toxin A activated the pro-apoptotic factor, caspase-3 [18]. Notably, both the increase in TUNELpositive cells and activation of caspase- 3 were significantly
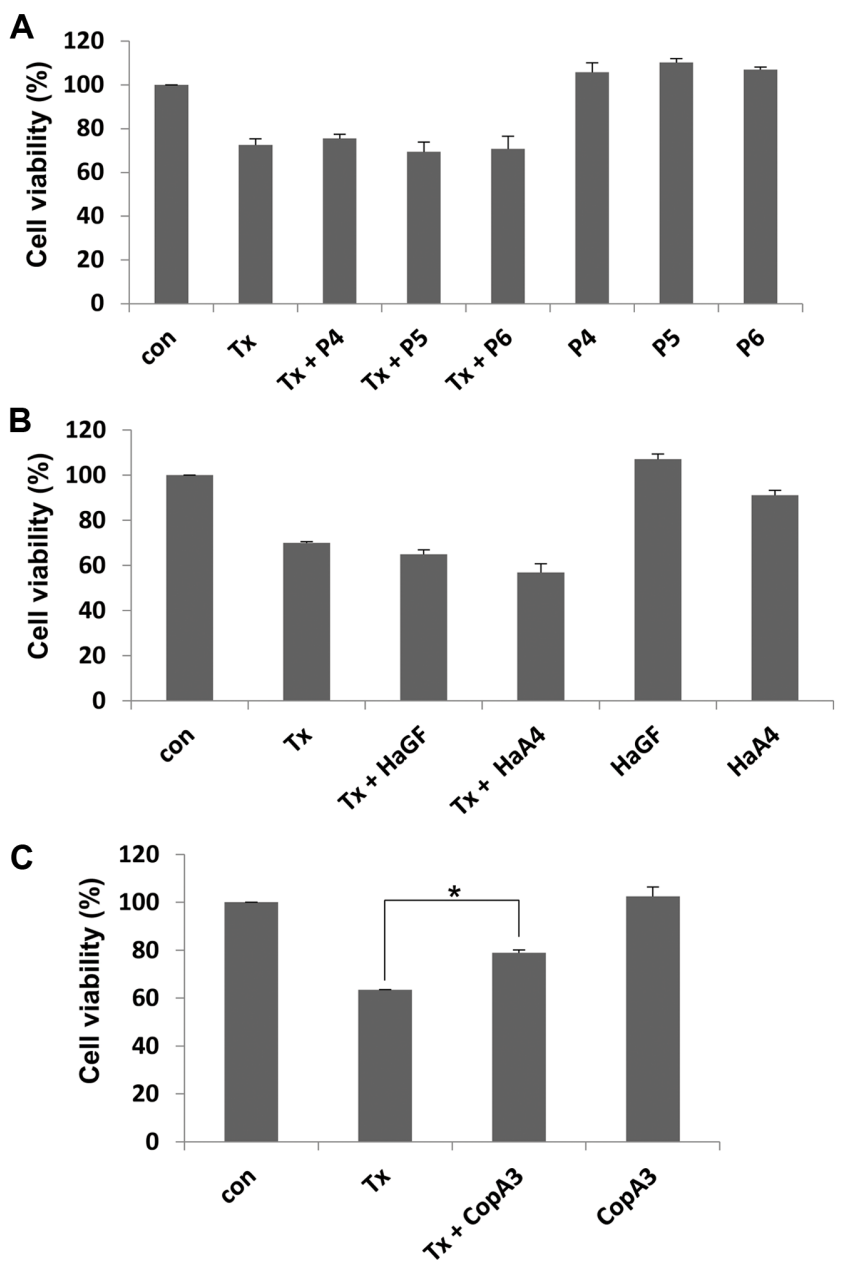

Fig. 1. The antimicrobial peptide CopA3 rescues the loss of neural cell viability caused by toxin A.

(A) Human neuroblastoma SH-SY5Y cells $\left(10^{5}\right.$ cells/well) were treated with medium (con), toxin $\mathrm{A}(\mathrm{Tx} ; 3 \mathrm{nM})$ alone, or toxin $\mathrm{A}$ together with $10 \mu \mathrm{g} / \mathrm{ml}$ of $P$. brevitarsis peptides (P4, P5, or P6) for $24 \mathrm{~h}$, and then cell viability was measured by MTT assay. The results are expressed as percentages and represent means \pm SEM from three experiments performed in triplicate. (B) SH-SY5Y cells were treated with medium (con), toxin $\mathrm{A}(\mathrm{Tx} ; 3 \mathrm{nM})$ alone, toxin $\mathrm{A}$ together with $10 \mu \mathrm{g} / \mathrm{ml}$ of $\mathrm{H}$. axyridis peptide (HaGF or HaA4) for $24 \mathrm{~h}$. The results are expressed as percentages and represent means \pm SEM from three experiments performed in triplicate. (C) SH-SY5Y cells were treated with medium (con), toxin $\mathrm{A}(\mathrm{Tx} ; 3 \mathrm{nM})$ alone, toxin A plus CopA3 $(10 \mu \mathrm{g} / \mathrm{ml})$, or CopA3 $(10 \mu \mathrm{g} / \mathrm{ml})$ alone for $24 \mathrm{~h}\left({ }^{*}, p<0.005\right)$.

decreased by CopA3 treatment (Fig. 2B). Taken together with findings noted above, these results indicate that CopA3 is capable of inhibiting multiple types of damage caused by toxin A, including viability loss and apoptosis.

The prevailing view is that the cellular toxicity of toxin A requires the presence of a plasma membrane receptor on 
A
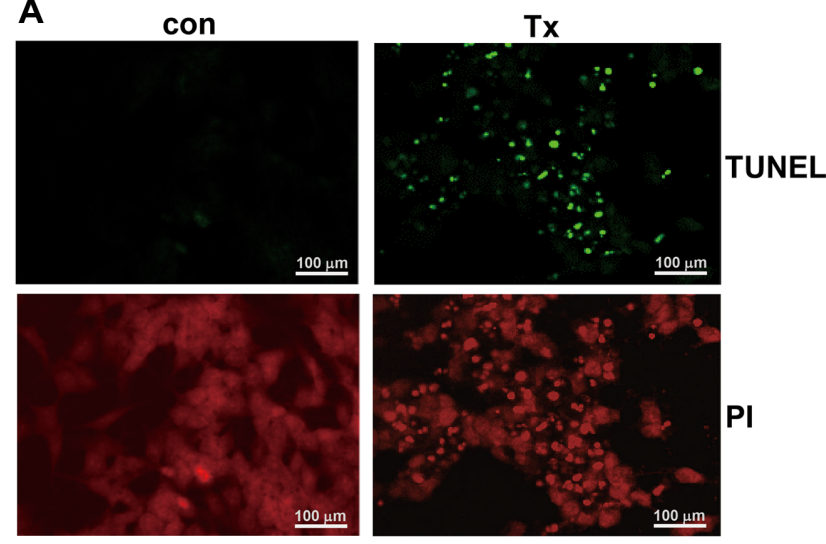

Tx + CopA3
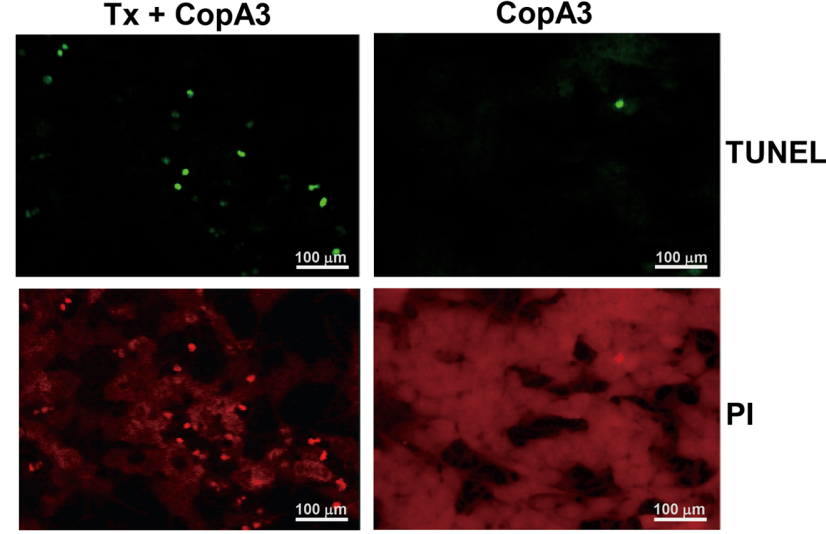

B

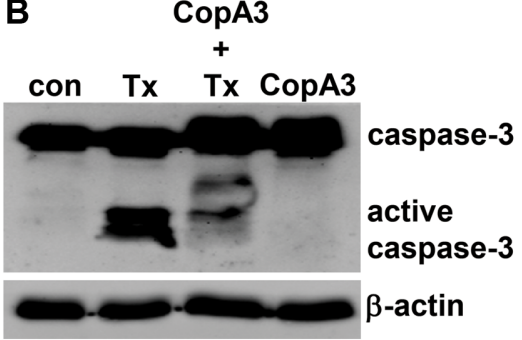

Fig. 2. The antimicrobial peptide CopA3 inhibits toxin Ainduced apoptosis in human neural cells.

(A) Human neuroblastoma SH-SY5Y cells $\left(10^{5}\right.$ cells/well) were treated with medium (con), toxin $\mathrm{A}(\mathrm{Tx} ; 3 \mathrm{nM})$ alone, toxin A plus CopA3 $(10 \mu \mathrm{g} / \mathrm{ml})$, or CopA3 $(10 \mu \mathrm{g} / \mathrm{ml})$ alone for $24 \mathrm{~h}$. DNA fragmentation was detected by TUNEL assay (green spots indicate apoptosis). Nuclei were counterstained with propidium iodide (PI) in all cases. Results are representative of three independent experiments. (B) Cells were treated as described in $\mathbf{A}$, and caspase- 3 activity was assessed by immunoblotting. Cells were lysed, cellular proteins were resolved by SDS-PAGE on $10 \%$ gels, and blots were probed with the indicated antibodies. Results are representative of three independent experiments.

the target cells [9]. The observation that toxin A was cytotoxic towards human neural cells clearly implies the presence of a plasma membrane receptor that can bind toxin A. Although the receptor that binds toxin A has not been identified, because CopA3 is composed of positively charged amino acid, it has been speculated that the receptor is likely a negatively charged protein [25].

CopA3, an antimicrobial peptide, exhibits antiapoptotic effects on both OHDA- and okadaic acid (OA)-induced neural cell apoptosis [25]. Indeed, studies using various human cells have reported that many antimicrobial peptides exhibit enormous therapeutic potential $[5,22,31]$. For example, the antimicrobial peptide Lumbricusin, isolated from earthworms, is reported to protect neural cells from stress-induced apoptosis [25]. The antimicrobial peptide periplanetasin-2, derived from the American cockroach, also displays antiapoptotic activity against colonic epithelial cell apoptosis caused by toxin A [10]. These results indicate that the antibacterial function of these peptides against prokaryotic microbes can exhibit different biological activities in eukaryotic human cells.

Toxin A-induced cell rounding is a typical morphological change associated with cell damage [12-14, 18, 19]. Consistent with this, we found that toxin A clearly induced rounding of neural cells compared with medium-treated cells; however, unlike the apoptotic effect of toxin $\mathrm{A}$, this effect of toxin A was not rescued by CopA3 (data not shown). On the basis of previous reports that toxin A-induced cell rounding depends on inactivation of Rho family proteins that are known to regulate neural cell cytoskeleton formation $[9,12,13]$, we infer that the ability of CopA3 to inhibit cell apoptosis is not related to regulation of Rho family proteins.

\section{A Cysteine Residue Is Critical for the Neuroprotective Effects of CopA3}

We next tested whether a cysteine residue in the middle region of CopA3 (LL-C-IALRKK) contributes to its ability to inhibit toxin A-induced neural cell toxicity. To this end, we incubated SH-SY5Y cells with toxin A, together with CopA3 or a CopA3-CS mutant in which this cysteine residue is replaced with a serine (LL-S-IALRKK) [29] for $24 \mathrm{~h}$ and measured cell viability by MTT assay. As shown in Fig. 3A, unlike CopA3, the CopA3-CS mutant had no inhibitory effect on toxin A-induced loss of neural cell viability. But like CopA3, CopA3-CS mutant alone showed no cytotoxicity towards neural cells (Fig. 3A). The CopA3CS mutant also slightly inhibited toxin A-induced caspase3 activation (Fig. 3B). These results suggest the importance of this cysteine residue in the neuroprotective effects of CopA3. A cysteine residue is also essential for the functional effects of defensin, another antimicrobial peptide. Like 


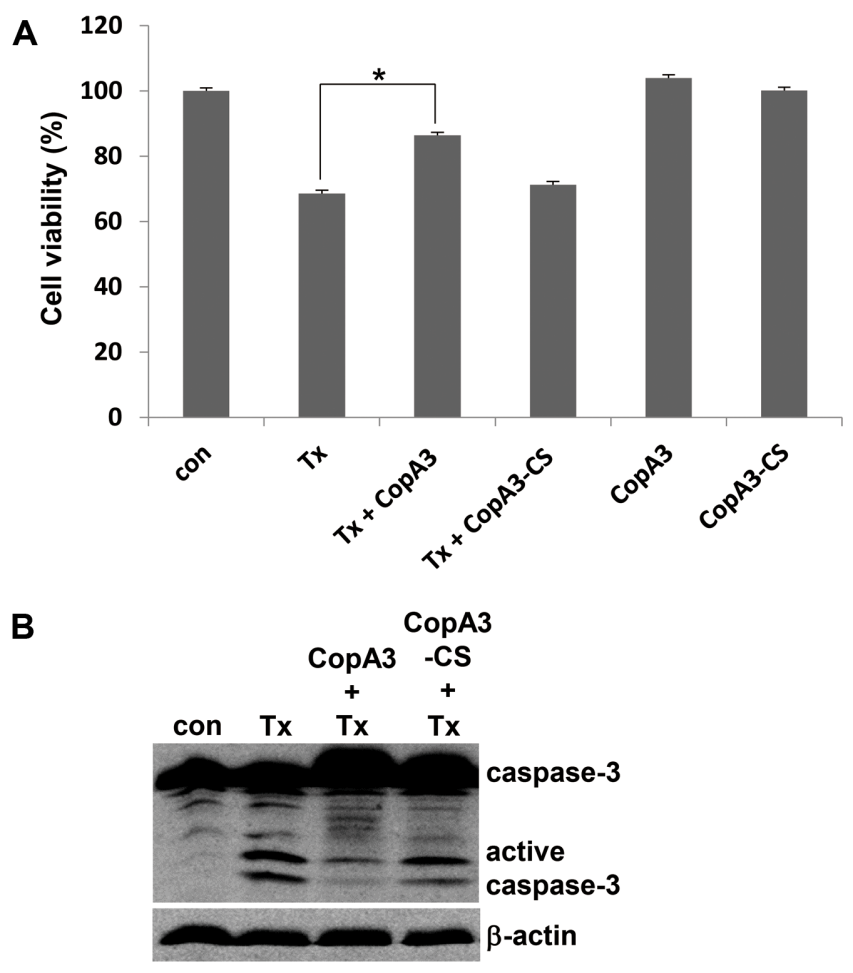

Fig. 3. The cysteine residue in CopA3 is critical for its neuroprotective activity.

(A) Human neuroblastoma SH-SY5Y cells $\left(10^{5}\right.$ cells/well) were treated with medium (con), toxin $\mathrm{A}$ ( $\mathrm{Tx} ; 3 \mathrm{nM})$ alone, CopA3 $(10 \mu \mathrm{g} / \mathrm{ml}$, LLCIALRKK) alone, CopA3-CS mutant $(10 \mu \mathrm{g} / \mathrm{ml}$, LLSIALRKK) alone, toxin A plus CopA3, or toxin A plus CopA3-CS mutant for $24 \mathrm{~h}$, and cell viability was measured by MTT assay. Results represent means \pm SEM of three experiments performed in triplicate $\left.{ }^{*}, p<0.005\right)$. (B) SH-SY5Y cells were treated with medium (con), toxin A ( Tx; $3 \mathrm{nM})$ alone, toxin A plus CopA3 $(10 \mu \mathrm{g} / \mathrm{ml})$, or toxin A plus CopA3CS mutant $(10 \mu \mathrm{g} / \mathrm{ml})$ for $24 \mathrm{~h}$. Caspase-3 activity was assessed by immunoblotting. Results are representative of three independent experiments.

defensin, CopA3 may require this cysteine residue to maintain a critical structure that allows it to easily enter the plasma membrane of target cells. Glutathione, which contains a cysteine-like sulfhydryl group that is critical for its functional activity, is another such example (54). The chicken-derived antimicrobial peptide, gallinacin, also contains a cysteine residue and has primary sequence homology to $\beta$-defensin [8].

The Neuroprotective Effects of CopA3 Are Not Associated with ROS/p38 MAPK/p27 $7^{\text {kip1 }}$ Signaling, a Well-Known Toxin A-Activated Pathway

In our previous study, we found that CopA3 substantially increased proliferation of neural cells [25] and abrogated
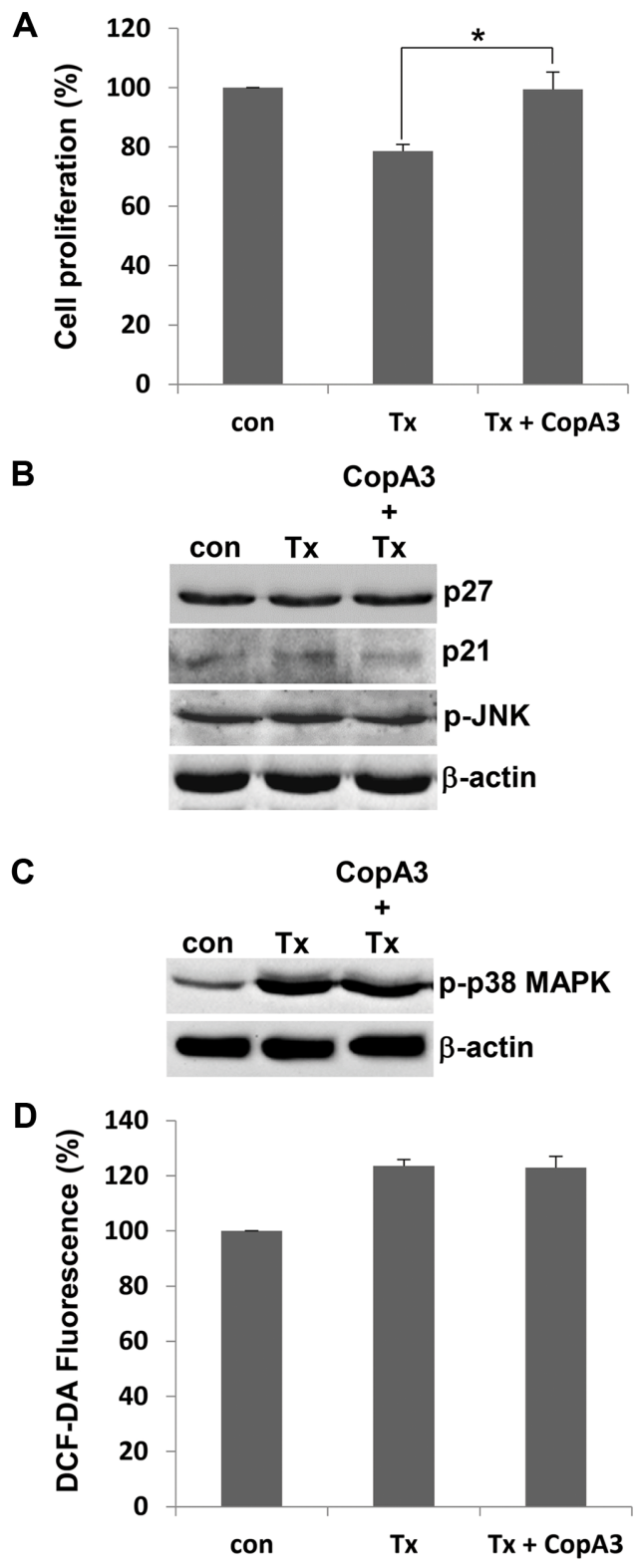

Fig. 4. CopA3 does not target a well-known toxin A-activated signaling pathway to inhibit toxin A-induced neural cell toxicity. (A) Human neuroblastoma SH-SY5Y cells (10 cells/well) were treated with medium (con), toxin $\mathrm{A}(\mathrm{Tx} ; 3 \mathrm{nM})$ alone, or toxin A plus CopA3 $(10 \mu \mathrm{g} / \mathrm{ml})$ for $48 \mathrm{~h}$. Cell proliferation was assessed by measuring BrdU uptake. Results represent means \pm SEM of three experiments performed in triplicate $\left({ }^{*}, p<0.005\right)$. (B and C) SH-SY5Y cells $\left(10^{5}\right.$ cells/well $)$ were treated as described in $\mathbf{A}$, and lysed. Thereafter cellular proteins were resolved by SDS-PAGE on $10 \%$ gels, and blots were probed with the indicated antibodies. Results are representative of three independent experiments. (D) SH-SY5Y cells were treated with medium, toxin A alone or toxin A plus CopA3 for $1 \mathrm{~h}$, and further incubated with DCFH-DA $(50 \mu \mathrm{M})$ for $15 \mathrm{~min}$. Changes in fluorescence intensity were monitored. The bars represent means \pm SEM from three independent experiments performed in triplicate. 
apoptosis induced by 6-OHDA or OA [25]. Extending these results, we examined whether toxin A decreases neural cell proliferation, and whether the decrease in cell proliferation induced by toxin A can be rescued by CopA3 treatment. To this end, we incubated SH-SY5Y cells with toxin A, with or without CopA3, for $48 \mathrm{~h}$ and measured DNA synthesis by BrdU uptake assay [17]. As shown in Fig. 4A, toxin A decreased DNA synthesis by up to $35 \%$. Notably, this inhibitory effect was significantly attenuated by CopA3 treatment, suggesting that the ability of CopA3 to increase proliferation may be critical for protection against toxin Ainduced neural cell apoptosis. Since CopA3-induced downregulation of $\mathrm{p} 27^{\mathrm{kip} 1}$, a cell cycle inhibitor, is critical for the neurotropic activity of CopA3 in 6-OHDA-induced neural cell apoptosis [25], we next measured p27 ${ }^{\text {kip1 }}$ expression levels after treatment with toxin A plus CopA3. Unexpectedly, we found no marked change in p27 $7^{\mathrm{kip} 1}$ expression levels in the presence of CopA3 (Fig. 4B). Moreover, expression of $\mathrm{p}^{\mathrm{CTP} 1 / \mathrm{WAF} 1}$, an essential cell cycle regulator [17], was also unchanged, suggesting that $\mathrm{p} 21^{\mathrm{CIP} 1 / \mathrm{WAF} 1}$ and $\mathrm{p} 27^{\mathrm{kip} 1}$, the main regulators of cell-cycle arrest, are not critical components of the neuroprotective activity of CopA3 against toxin A. In gut epithelial cells, toxin A-induced apoptosis is known to depend on ROS generation and subsequent activation of the downstream effector, p38 MAPK [18, 19]. Accordingly, we measured ROS levels and p38 MAPK activation following treatment of SH-SY5Y cells with toxin A, with or without CopA3, for $48 \mathrm{~h}$. As expected, toxin A induced a rapid increase in ROS levels and activated p38 MAPK; however, CopA3 had no effect on either of these actions of toxin A (Fig. 4C). These results suggest that the neuroprotective effects of CopA3 do not reflect targeting of toxin A-induced ROS production, p38 MAPK and $\mathrm{p} 27^{\mathrm{kip} 1}$ activation.

Taken together, our findings indicate that the antimicrobial peptide CopA3 inhibits toxin A-induced neural cell damage, and suggest the novel idea that the neuroprotective effects of CopA3 can relieve gut inflammatory responses caused by toxin A-induced ENS damage.

\section{Acknowledgments}

This work was supported by a grant from the NextGeneration BioGreen 21 Program (no, PJ01325602), Rural Development Administration, Republic of Korea.

\section{Conflict of Interest}

The authors have no financial conflicts of interest to declare.

\section{References}

1. Camilleri M, Nullens S, Nelsen T. 2012. Enteroendocrine and neuronal mechanisms in pathophysiology of acute infectious diarrhea. Dig. Dis. Sci. 57: 19-27.

2. Castagliuolo I, LaMont JT, Letourneau R, Kelly C, O'Keane JC, Jaffer A, et al. 1994. Neuronal involvement in the intestinal effects of Clostridium difficile toxin A and Vibrio cholerae enterotoxin in rat ileum. Gastroenterology 107: 657-665.

3. Chen X, Katchar K, Goldsmith JD, Nanthakumar N, Cheknis A, Gerding DN, et al. 2008. A mouse model of Clostridium difficile-associated disease. Gastroenterology 135: 1984-1992.

4. Choi H, Hwang JS, Kim H, Lee DG. 2013. Antifungal effect of CopA3 monomer peptide via membrane-active mechanism and stability to proteolysis of enantiomeric D-CopA3. Biochem. Biophys. Res. Commun. 440: 94-98.

5. Chowanski S, Adamski Z, Lubawy J, Marciniak P, Pacholska-Bogalska J, Slocinska M, et al. 2017. Insect peptides - perspectives in human diseases treatment. Curr. Med. Chem. 24: 3116-3152.

6. Dillon ST, Rubin EJ, Yakubovich M, Pothoulakis C, LaMont JT, Feig LA, et al. 1995. Involvement of Ras-related Rho proteins in the mechanisms of action of Clostridium difficile toxin A and toxin B. Infect. Immun. 63: 1421-1426.

7. Goyal RK, Hirano I. 1996. The enteric nervous system. N. Engl. J. Med. Overseas Ed. 334: 1106-1115.

8. Harwig SS, Swiderek KM, Kokryakov VN, Tan L, Lee TD, Panyutich EA, et al. 1994. Gallinacins: cysteine-rich antimicrobial peptides of chicken leukocytes. FEBS Lett. 342: 281-285.

9. He D, Hagen SJ, Pothoulakis C, Chen M, Medina ND, Warny M, et al. 2000. Clostridium difficile toxin A causes early damage to mitochondria in cultured cells. Gastroenterology 119: 139-150.

10. Hong J, Zhang P, Yoon IN, Hwang JS, Kang JK, Kim H. 2017. The American cockroach peptide periplanetasin-2 blocks Clostridium Difficile toxin A-induced cell damage and inflammation in the gut. J. Microbiol. Biotechnol. 27: 694-700.

11. Hwang JS, Lee J, Kim YJ, Bang HS, Yun EY, Kim SR, et al. 2009. Isolation and characterization of a defensin-like peptide (coprisin) from the dung beetle, copris tripartitus. Int. J. Pept. 2009

12. Just I, Wilm M, Selzer J, Rex G, von Eichel-Streiber C, Mann M, et al. 1995. The enterotoxin from Clostridium difficile (ToxA) monoglucosylates the Rho proteins. J. Biol. Chem. 270: 1393213936.

13. Just I, Selzer J, Hofmann F, Green GA, Aktories K. 1996. Inactivation of Ras by Clostridium sordellii lethal toxincatalyzed glucosylation. J. Biol. Chem. 271: 10149-10153.

14. Kelly CP, Pothoulakis C, LaMont JT. 1994. Clostridium difficile colitis. N. Engl. J. Med. 330: 257-262.

15. Kim BY, Lee KS, Choo YM, Kim I, Hwang JS, Sohn HD, Jin BR. 2008. Molecular cloning and characterization of a 
transferrin cDNA from the white-spotted flower chafer, Protaetia brevitarsis. DNA Seq. 19: 146-150.

16. Kim DH, Lee IH, Nam ST, Hong J, Zhang P, Hwang JS, et al. 2014. Neurotropic and neuroprotective activities of the earthworm peptide Lumbricusin. Biochem. Biophys. Res. Commun. 448: 292-297.

17. Kim DH, Hwang JS, Lee IH, Nam ST, Hong J, Zhang P, et al. 2016. The insect peptide CopA3 increases colonic epithelial cell proliferation and mucosal barrier function to prevent inflammatory responses in the gut. J. Biol. Chem. 291: 3209-3223.

18. Kim H, Kokkotou E, Na X, Rhee SH, Moyer MP, Pothoulakis C, et al. 2005. Clostridium difficile toxin A-induced colonocyte apoptosis involves p53-dependent p21(WAF1/ CIP1) induction via p38 mitogen-activated protein kinase. Gastroenterology 129: 1875-1888.

19. Kim H, Rhee SH, Kokkotou E, Na X, Savidge T, Moyer MP, et al. 2005. Clostridium difficile toxin A regulates inducible cyclooxygenase-2 and prostaglandin E2 synthesis in colonocytes via reactive oxygen species and activation of p38 MAPK. J. Biol. Chem. 280: 21237-21245.

20. Kim H, Rhee SH, Pothoulakis C, Lamont JT. 2007. Inflammation and apoptosis in Clostridium difficile enteritis is mediated by PGE2 up-regulation of Fas ligand. Gastroenterology 133: $875-886$.

21. Kim IW, Lee JH, Park HY, Kwon YN, Yun EY, Nam SH, et al. 2012. Characterization and cDNA cloning of a defensin-like peptide, harmoniasin, from Harmonia axyridis. J. Microbiol. Biotechnol. 22: 1588-1590.

22. Leite ML, da Cunha NB, Costa FF. 2018. Antimicrobial peptides, nanotechnology, and natural metabolites as novel approaches for cancer treatment. Pharmacol. Ther. 183: 160176.

23. Na X, Zhao D, Koon HW, Kim H, Husmark J, Moyer MP, et al. 2005. Clostridium difficile toxin B activates the EGF receptor and the ERK/MAP kinase pathway in human colonocytes. Gastroenterology 128: 1002-1011.

24. Nam HJ, Oh AR, Nam ST, Kang JK, Chang JS, Kim DH, et al. 2012. The insect peptide CopA3 inhibits lipopolysaccharideinduced macrophage activation. J. Pept. Sci.18: 650-656.

25. Nam ST, Kim DH, Lee MB, Nam HJ, Kang JK, Park MJ, et al. 2013. Insect peptide CopA3-induced protein degradation of p27Kip1 stimulates proliferation and protects neuronal cells from apoptosis. Biochem. Biophys. Res. Commun. 437: 35-40.
26. Poli E, Lazzaretti M, Grandi D, Pozzoli C, Coruzzi G. 2001. Morphological and functional alterations of the myenteric plexus in rats with TNBS-induced colitis. Neurochem. Res. 26: 1085-1093.

27. Pothoulakis C, Lamont JT. 2001. Microbes and microbial toxins: paradigms for microbial-mucosal interactions II. The integrated response of the intestine to Clostridium difficile toxins. Am. J. Physiol. Gastrointest. Liver Physiol. 280: G178183.

28. Reinshagen M, Rohm H, Steinkamp M, Lieb K, Geerling I, Von Herbay A, et al. 2000. Protective role of neurotrophins in experimental inflammation of the rat gut. Gastroenterology 119: $368-376$.

29. Ren X, Kasir J, Rahamimoff H. 2001. The transport activity of the Na+-Ca2+ exchanger NCX1 expressed in HEK 293 cells is sensitive to covalent modification of intracellular cysteine residues by sulfhydryl reagents. J. Biol. Chem. 276: 9572-9579.

30. Rhee SH, Im E, Riegler M, Kokkotou E, O'Brien M, Pothoulakis C. 2005. Pathophysiological role of Toll-like receptor 5 engagement by bacterial flagellin in colonic inflammation. Proc. Natl. Acad. Sci. USA 102: 13610-13615.

31. Roudi R, Syn NL, Roudbary M. 2017. Antimicrobial peptides as biologic and immunotherapeutic agents against cancer: a comprehensive overview. Front Immunol. 8: 1320.

32. Shin S, Kim JK, Lee JY, Jung KW, Hwang JS, Lee J, et al. 2009. Design of potent 9-mer antimicrobial peptide analogs of protaetiamycine and investigation of mechanism of antimicrobial action. J. Pept. Sci. 15: 559-568.

33. Xia Y, Hu HZ, Liu S, Pothoulakis C, Wood JD. 2000. Clostridium difficile toxin $\mathrm{A}$ excites enteric neurones and suppresses sympathetic neurotransmission in the guinea pig. Gut 46: 481-486.

34. Yu SJ, Grider JR, Gulick MA, Xia CM, Shen S, Qiao LY. 2012. Up-regulation of brain-derived neurotrophic factor is regulated by extracellular signal-regulated protein kinase 5 and by nerve growth factor retrograde signaling in colonic afferent neurons in colitis. Exp. Neurol. 238: 209-217.

35. Zhang P, Hong J, Yoon IN, Kang JK, Hwang JS, Kim H. 2017. Clostridium difficile toxin A induces reactive oxygen species production and p38 MAPK activation to exert cellular toxicity in neuronal cells. J. Microbiol. Biotechnol. 27: 1163-1170. 